JOEAI (Journal of Education and Instruction)

Volume 1, Nomor 2, Desember 2018

e-ISSN : 2614-8617

p-ISSN : 2620-7346

DOI: https://doi.org/10.31539/joeai.v1i2.396

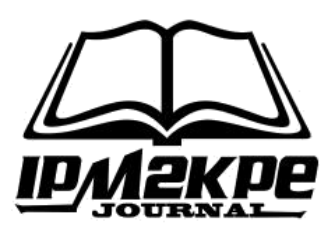

\title{
PENERAPAN MODEL THINK PAIR SHARE PADA PEMBELAJARAN FISIKA
}

\author{
Leo Charli ${ }^{1}$, Ahmad Amin ${ }^{2}$, Indah Pujiastuti ${ }^{3}$ \\ STKIP-PGRI Lubuklinggau ${ }^{1,2,3}$ \\ Leocharli2018@gmail.com ${ }^{1}$
}

\begin{abstract}
ABSTRAK
Tujuan penelitian untuk menerapkan model think pair share pada pembelajaran fisika. Jenis penelitian yang digunakan adalah eksperimen semu dengan desain pre-test and post-test group. Populasinya adalah seluruh siswa kelas VII yang terdiri dari 3 kelas berjumlah 95 siswa. Sampel diambil secara acak dan kelas yang terpilih adalah kelas VII.2 yang berjumlah 32 siswa. Data dikumpulkan menggunakan teknik tes yang dianalisis menggunakan uji-t pada taraf signifikan $\alpha=0,05$. Berdasarkan hasil perhitungan uji-t diperoleh $t_{\text {hitung }}(2,05)>t_{\text {tabel }}(1,71)$, sehingga hasil belajar fisika dengan menggunakan model Think Pair Share secara signifikan tuntas. Rata-rata hasil belajar siswa sebesar 67,85 dan persentase siswa yang tuntas sebesar $81,25 \%$. Simpulan, penerapan model think pair share sangatlah tepat dalam pembelajaran fisika.
\end{abstract}

Kata Kunci : Belajar Fisika, Hasil belajar, Think Pair Share.

\section{ABSTRACT}

This study aims to determine the effectiveness of contextual teaching learning models and community technology science models on student learning outcomes in the diffusion courses of educational innovation. This study uses quasiexperimental by collecting data using tests, documentation, interviews and observations. The results showed that the average value of student learning outcomes used in the learning model of community technology science was higher than the value of student learning outcomes used in the contextual teaching learning model. This is because the community's science technology model helps students better understand material related to problems found in real life so students become active in the learning process. In conclusion, the Contextual Teaching and Science learning model of community technology is more effective in improving student learning outcomes in the diffusion of education innovation courses.

Keywords: Learning Physics, Learning Outcomes, Think Pair Share.

\section{PENDAHULUAN}

Pendidikan merupakan tugas negara yang amat penting, setiap bangsa dan negara perlu mempersiapkan segala hal dalam menghadapi pengaruh perkembangan teknologi terhadap pendidikan untuk peningkatan kualitas pendidikan. Kualitas pendidikan sebagai salah satu pilar pengembangan sumber 
daya manusia (SDM), bermakna strategis bagi pembangunan nasional. Dengan meningkatnya kualitas pendidikan diharapkan akan menghasilkan Sumber Daya Manusia (SDM) yang berkemampuan unggul yaitu manusia yang beriman dan bertaqwa kepada Tuhan YME, berakhlak mulia, sehat, berilmu, cakap, kreatif dan mandiri sehingga mampu menghadapi kemajuan ilmu pengetahuan dan teknologi yang sedemikian pesat (Charli, 2017).

Pendidikan memiliki dunia belajar dan mengajar yang merupakan interaksi antara siswa dengan guru. Guru sebagai motivasi bagi siswa dalam proses belajar. Belajar merupakan proses melihat, mengamati, dan memahami, Sudjana (dalam Rusman, 2012). Dengan adanya belajar terbentuklah kelompok-kelompok siswasiswa yang aktif berinteraksi antar mereka untuk mencari solusi dalam pemecahan masalah.Tujuan pendidikan dalam dunia belajar yang diharapkan sulit tercapai apabila disini siswa terlalau sering dianggap sebagai objek pembelajaran dengan kegiatan yang mengutamakan pembentukan intelektual, dan tidak sering melatih mereka menjadi insan yang kreatif, kurang mandiri, dan kurang interaksi antar mereka. Dalam pembelajaran fisika tujuan yang diinginkan agar tecapainya keberhasilan dalam pembelajaran merupakan suatu hal yang perlu diperjuangkan dengan sunguh-sunguh, akan tetapi tujuan untuk tercapainya keberhasilan terhambat yang bisa disebabkan oleh salah satunya siswa kurang aktif dalam proses belajar, sehingga potensi yang ada dalam dirinya kurang berkembang.

Berdasarkan hasil observasi awal sebelum penulis melakukan penelitian di SMP Negeri Sumber Rejo tahun pelajaran 2017/2018 tersebut diperoleh data bahwa rata-rata hasil ulangan harian di kelas VII SMP Negeri Sumber Rejo sebesar 40 dan masih dibawah Kriteria Ketuntasan Minimum (KKM), dimana (KKM) yang ditetapkan tersebut adalah 60, Jumlah siswa yang tuntas hanya 38 dari 95 siswa atau 40\%, dan siswa yang belum tuntas sebanyak 57 dari 95 siswa atau $60 \%$. Semua ini bukan semata-mata hanya kesalahan siswa tetapi dapat juga karena penggunaan model pembelajaran yang kurang tepat dan kurang diperhatikannya keterampilan proses selama pembelajaran fisika. Dalam interaksi ini, siswa akan membentuk komunitas yang memungkinkan mereka untuk mencintai proses belajar mengajar.

Dalam suasana belajar yang penuh persaingan, sikap dan hubungan yang negatif akan terbentuk dan mematikan semangat siswa. Suasana seperti ini akan menghambat pembentukan pengetahuan secara aktif. Oleh karena itu, pengajar perlu menciptakan suasana belajar yang sedemikian rupa, sehingga siswa bekerja sama dalam belajar. Untuk mengatasi hal tersebut penulis akan melakukan penelitian dengan menggunakan model pembelajaran Think Pair Share supaya bisa meningkatkan hasil belajar. Menurut Trianto (2009) bahwa Think Pair Share merupakan jenis pembelajaran kooperatif yang dirancang untuk mempengaruhi pola interaksi perilaku siswa.

Model Think Pair Share (TPS) atau berpikir berpasangan berbagi adalah merupakan jenis pembelajaran kooperatif yang dirancang untuk mempengaruhi 
pola interaksi siswa. Pertama kali dikembangkan oleh Frang Lyman dan koleganya di Universitas Maryland sesuai dengan pendapat Arends (dalam Trianto, 2009) menyatakan bahwa Think Pair Share merupakan suatu cara yang efektif untuk membuat variasi suasana pola diskusi kelas. Karena Think Pair Share memberikan siswa waktu lebih banyak untuk berpikir, menjawab, saling membantu satu sama lain.

Menurut Suyatno (2009), langkah-langkah Model Think Pair Share sebagai berikut 1) Guru menyampaikan inti materi dan kompetensi yang ingin dicapai, 2) Siswa diminta untuk berpikir tentang materi permasalahan yang disampaikan guru, 3) Siswa diminta berpasangan dengan teman sebelahnya (1 kelompok 2 orang) dan mengutarakan hasil diskusinya, 4) Guru memimpin diskusi, tiap kelompok mengemukakan hasil diskusinya, 5) Berawal dari kegiatan tersebut, arahkan pembicaraan pada pokok permasalahan, 6) Guru memberi kesimpulan, 7) Penutup. Menurut pendapat Hidayati (2015) salah satu kelemahan model pembelajaran Think Pair Share adalah Jumlah siswa yang ganjil berdampak pada saat pembentukan kelompok, karena ada satu siswa tidak mempunyai pasangan.

Berdasarkan uraian diatas maka artikel ini secara fokus membahas tentang penerapan model think pair share pada pembelajaran fisika, adapun tujuan penelitian ini adalah untuk menerapkan model think pair share pada pembelajaran fisika pada siswa SMP N Sumber Rejo.

\section{METODE PENELITIAN}

Penelitian ini dilakukan di SMP Negeri Sumber Rejo Tahun Pelajaran 2017/2018. Metode penelitian adalah cara yang digunakan oleh peneliti dalam mengumpulkan data penelitiannya (Arikunto, 2010). Metode penelitian yang digunakan dalam penelitian ini adalah metode eksperimen semu. Desain penelitian yang digunakan dalam penelitian ini adalah Pre-test and Post-test group design.

Variabel bebas dalam penelitian ini adalah model Think Pair Share sedangkan variabel terikatnya adalah hasil belajar fisika siswa kelas VII. Sugiyono (2010) populasi adalah wilayah generalisasi yang terdiri atas: obyek/subyek yang mempunyai kualitas dan karakteristik tertentu yang ditetapkan oleh peneliti untuk kemudian ditarik kesimpulannya. Populasi dalam penelitian ini adalah seluruh siswa kelas VII SMP Negeri Sumber Rejo Tahun Pelajaran 2017/2018. Teknik pengumpulan data yang digunakan dalam penelitian ini adalah teknik tes. Tes yang digunakan dalam penelitian ini berbentuk essay yang berfungsi untuk menilai hasil belajar siswa. 


\section{HASIL DAN PEMBAHASAN}

\section{Deskripsi hasil data Pre-test}

Sebelum proses belajar mengajar dilakukan terlebih dahulu peneliti melakukan Pre-tes pada pertemuan pertama. Tujuan pelaksanaan Pre-test untuk mengetahui kemampuan awal siswa sebelum pembelajaran fisika dengan menggunakan model pembelajaran Thin Pair Share diterapkan di kelas. Hasil Pre-test dapat dilihat pada tabel 1.

Tabel 1

Data hasil Pre-test

\begin{tabular}{clc}
\hline No & \multicolumn{1}{c}{ Kategori } & Keterangan \\
\hline 1 & Rata-rata & 32,43 \\
\hline 2 & Simpangan baku & 10,703 \\
\hline 3 & Nilai tertinggi & 48 \\
\hline 4 & Nilai terendah & 12 \\
\hline 5 & Siswa yang tuntas & $0(0 \%)$ \\
\hline 6 & Siswa yang tidak tuntas & $32(100 \%)$ \\
\hline
\end{tabular}

\section{Deskripsi hasil data Post-test}

Pelaksanaan post-test berfungsi untuk mengetahui hasil belajar siswa setelah mengikuti kegiatan pembelajaran fisika dengan menggunakan model Think Pair Share. Analisis hasil post-test siswa dapat dilihat pada tabel 2.

Tabel 2

Data hasil Post-test

\begin{tabular}{|c|c|c|}
\hline No & Kategori & Keterangan \\
\hline 1 & Rata-rata & 67,85 \\
\hline 2 & Simpangan baku & 21,70 \\
\hline 3 & Nilai tertinggi & 100 \\
\hline 4 & Nilai terendah & 22 \\
\hline 5 & Siswa yang tuntas & $26(81,25 \%)$ \\
\hline 6 & Siswa yang tidak tuntas & $6(18,75 \%)$ \\
\hline
\end{tabular}

Berdasarkan hasi pre-test dan post-test dietahui bahwa hasil belajar fisika siswa kelas VII SMP Negeri Sumber Rejo tahun ajaran 2017/2018 setelah penerapan model pembelajaran Think Pair Share secara signifikan tuntas. Jika dibandingkan dengan pre-test, maka terdapat peningkatan rata-rata nilai sebesar 67,85 dan peningkatan persentase jumlah siswa yang tuntas sebesar 81,25\%. Perbandingan nilai rata-rata dan ketuntasan hasil belajar dapat dilihat pada grafik berikut. 


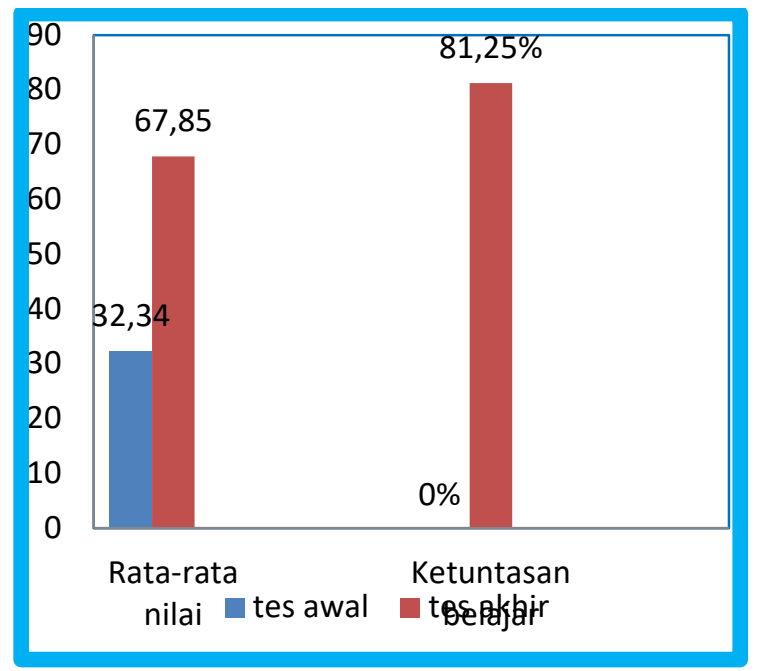

Grafik 1. Peningkatan nilai rata-rata dan ketuntasan belajar.

Berdasarkan pada rumusan masalah yang dikemukakan dalam penelitian ini adalah "Apakah hasil belajar Fisika siswa kelas VII SMP Negeri Sumber Rejo Tahun Pelajaran 2017/2018 setelah penerapan model Think Pair Share secara signifikan tuntas ?". Berdasarkan hasil belajar kelas VII.2 yang dijadikan sampel penelitian dapat diketahui jika setelah pemberian pre-test dan post-test. Dari analisis data pre-test bahwa tidak ada siswa yang mendapatkan nilai lebih dari 60 (tuntas). Rata-rata nilai siswa secara keseluruhan $(32,43)$, dapat disimpulkan hasil pre-test sebelum diterapkan model Think Pair share belum tuntas. Hal ini terjadi karena siswa belum mempelajari materi tersebut sebelumnya. Setelah dilakukannya pre-test, peneliti melakukan pembelajaran dengan penerapan model Think Pair Share. Pembelajaran dilakukan sebanyak tiga kali pertemuan.

Pelaksanaan di kelas, pada pertemuan pertama pembelajaran dengan menerapkan model Think Pair Share mengalami kesulitan dan menemukan beberapa hambatan. Dikarenakan adanya perubahan cara mengajar guru dirasakan siswa sebagai hal yang baru dan memerlukan penyesuaian terhadap model pembelajaran baru tersebut. Pada pertemuan pertama kegaduhan terjadi di mana siswa yang belum terbiasa dengan pembelajaran kelompok cenderung bingung siapa saja anggota kelompoknya sehingga cukup menyita waktu belajar. Kemudian siswa masih bingung dengan aturan main yang ditetapkan guru, kapan mereka harus menyampaikan jawaban mereka, dan mereka cenderung merasa malu dan kurang percaya diri dalam mengeluarkan pendapat mereka.

Selanjutnya, guru menemui kesulitan dalam membagi waktu karena siswa masih malu dalam mengemukakan jawabannya sehingga membutuhkan waktu yang lama, dan kecurangan pun terjadi pada pertemuan pertama, di mana kelompok yang kurang sportif mengubah jawaban mereka sesuai dengan hasil pembahasan. Namun peneliti menemukan solusi untuk menghadapi hambatan ini pada pertemuan berikutnya. Adapun solusinya antara lain sebagai berikut : 
1. Pada pertemuan sebelumnya siswa sudah diberi tahu siapa saja anggota kelompoknya. Dalam menentukan kelompok siswa diminta berpasangan dengan teman yang lainnya, siswa yang pandai berpasangan dengan siswa yang kurang pandai. Sehingga pada pertemuan berikutnya tidak diperlukan waktu yang lama untuk membentuk kelompok.

2. Untuk pertemuan pertama, setiap kelompok diberikan beberapa waktu sepuluh menit untuk mencari jawaban. Namun, untuk pertemuan berikutnya setiap kelompok harus mempersiapkan jawabannya dalam waktu lima menit.

3. Untuk menghindari kecurangan, bagi kelompok yang sudah mendapatkan jawaban harus menyampaikan jawaban mereka dan ditunjukkan ke kelompok lainnya, sehingga peluang untuk mengubah jawaban bisa dihindari

Setelah peneliti menggunakan solusi di atas, hambatan yang terjadi pada saat proses belajar mengajar berlangsung, khususnya pada pertemuan pertama dengan materi kalor tidak lagi terjadi pada pertemuan-pertemuan berikutnya. Siswa terbiasa dengan pembelajaran kelompok dan mulai merasa tertarik dengan pembelajaran ini. Siswa merasa senang dalam bersaing dengan kelompok lain untuk memperoleh nilai tambah dari jawaban tercepat namun tepat. Kecurangan pun bisa dihindari, karena antar kelompok saling mengawasi jawaban kelompok lain, sehingga bisa mengurangi kecurangan yang terjadi. Siswa pun menjadi lebih antusias dalam menerima materi pelajaran.

Dari penelitian yang dilakukan terdapat 16 kelompok, pada pertemuan pertama jumlah kelompok yang dapat menyelesaikan tugas dengan benar ada 6 kelompok, selanjutnya pada pertemuan kedua terdapat 10 kelompok, dan pada pertemuan ketiga ada 15 kelompok. Berdasarkan penelitian yang telah dilakukan, bahwasanya penggunaan model Think Pair Share ini dapat dijadikan alternatif dalam proses belajar mengajar.

Hal ini dikarenakan model Think Pair Share merupakan suatu pendekatan pembelajaran dengan menggunakan kelompok kecil agar siswa dapat bekerja sama dalam memilih alternatif terbaik dalam memecahkan masalah. Dalam penerapannya siswa dituntut untuk mengungkapkan pendapat serta pengetahuan yang dimiliki, selain itu siswa dilatih untuk dapat saling berbagi saling mengajari sesama teman, jadi siswa juga dapat belajar dari sesama teman.

Dari hasil penelitian ini menunjukkan bahwa hasil belajar fisika siswa meningkat. Namun masih terdapat kendala yaitu beberapa siswa yang masih merasa malu-malu dan tidak percaya diri dalam mengemukakan pendapat pada saat pembelajaran berlangsung. Walaupun ada kendala mengenai keadaan siswa, hal ini tidak menyurutkan semangat dan konsentrasi siswa dalam belajar. Dapat dilihat dari hasil belajarnya, walaupun ada 6 orang siswa $(18,75 \%)$ yang belum mencapai kriteria ketuntasan minimum. Namun, hasil tersebut sudah mengalami peningkatan. 
Berdasarkan analisis secara statistik terbukti bahwa pembelajaran fisika dengan menggunakan model Think Pair Share dapat meningkatkan hasil belajar siswa.

\section{SIMPULAN}

Berdasarkan hasil penelitian dan pembahasan dapat dilihat dari uji hipotesis yang diperoleh yaitu $t_{\text {hitung }}(2,05)>t_{\text {tabel }}(1,71)$ sehingga dapat disimpulkan bahwa hasil belajar fisika siswa kelas VII SMP Negeri Sumber Rejo tahun ajaran 2017/2018 setelah penerapan model pembelajaran Think Pair Share secara signifikan tuntas.

\section{DAFTAR PUSTAKA}

Arikunto, S. (2010). Prosedur Penelitian Suatu Pendekatan Praktk. Jakarta: Rineke Cipta.

Charli, L., Amin, A., \& Agustina, D. (2018). Kesulitan Siswa dalam Menyelesaikan Soal Fisika pada Materi Suhu dan Kalor di Kelas X SMA Ar-Risalah Lubuklinggau Tahun Pelajaran 2016/2017. Journal of Education and Instruction (JOEAI), 1(1); 42-50. https://doi.org/https://doi.org/10.31539/joeai.v1i1.239

Lilis, H. (2015). Penerapan Model Think Pair Share Pada Pembelajaran Matematika Kelas X SMA Negeri Megang Sakti. Skripsi Tidak Diterbitkan. Lubuklinggau: Jurusan MIPA STKIP PGRI Lubuklinggau.

Rusman. (2012). Model-model Pembelajaran Mengembangkan Profesionalisme Guru. Bandung: Rajawali Pers.

Sugiyono. (2010). Statistika untuk Penelitian. Bandung: Alfabeta.

Suyatno. (2009). Menjelajah Pembelajaran Inovatif. Surabaya: Masme Dia Buana.

Trianto. (2009). Mendesain Model Pembelajaran Inovatif-Progresif. Surabaya: Prenada Media. 